\title{
JUN Family Gene
}

National Cancer Institute

\section{Source}

National Cancer Institute. JUN Family Gene. NCI Thesaurus. Code C17452.

JUN Family Genes encode nuclear leucine zipper JUN Family Proteins (JUN, JUNB, and JUND) that can homodimerize, or heterodimerize with nuclear leucine zipper FOS Family Proteins, to form the specific promoter/enhancer DNA binding AP-1 transcription factor complex that regulates target gene transcription in cell proliferation, differentiation, and transformation. $(\mathrm{NCl})$ 